\title{
To Correlate of Clinical and Biochemical Profile of the Uremic Patients: A Prospective Study
}

\author{
Author \\ Dr H.S. Chhabra \\ Principal Specialist (MD, Medicine), PDDU Government Hospital, Sagwara (Dungarpur) \\ Email:drchhabrahs@gmail.com, Mob. No.9414497636
}

\begin{abstract}
Background: In spite of extensive work on uremia until today the exact etiopathological agent responsible for the clinical toxicity of uremia could not be single out. Considering the sparsity of such studies which are a few in India and an attempt will be made to correlate them with clinical and biochemical profile of the uremic patients.

Material \& Methods: A prospective study done on 25 cases of uremia due to varied etiology were selected from the wards of general hospital, Dungarpur, Rajasthan. The cases were diagnosed on the basis of the criteria laid down by Jean Hamburger, Richet G. et al (1968). Cases were considered to be having renal failure if their blood urea level was over $50 \mathrm{mg} \%$ of these, those having urine output below $400 \mathrm{ml}$ per 24 hour were grouped as cases of acute renal failure and those having urine output $400 \mathrm{ml}$ were grouped as having chronic renal failure.

Results: Our study showed that maximum no. of cases (52\%) affected were from the range of 31-50 years, males were more preponderance as compared to females. In biochemical analysis, the blood urea and serum Creatinine was higher and serum sodium \& potassium within normal range. Out of 25 cases, 16 were alert and 9 cases were drowsy. Drowsy patients had elevated urea, Creatinine, and potassium levels and less sodium level as compared to alert patients.

Conclusion: We concluded that the blood urea and serum Creatinine was higher and serum sodium \& potassium within normal range. Hyponatremia and patients with blood urea above $201 \mathrm{mg} \%$ had relatively less significant positive correlation.

Keywords: Uremia, Serum urea, Biochemical analysis, Serum Creatinine, serum sodium, serum potassium.
\end{abstract}

\section{Introduction}

Until today the exact etiopathologic agent responsible for clinical toxicity in uremia could not be singled out. Various workers observed different findings in uremic cases. The encephalopathies appear to be more related to the rate of change of ion concentration than to the nature of the change of the involved ion.
Suppression of urine especially in cold weather was identified as a sign of bad omen by Hippocrates in the era 460 BC. Prevost and Dumas (1823) ans sir Robert Bright (1836) were early workers on this subjects. 'Uremia' term was coined in 1840 by piorry and L'Heiritier to describe the primary abnormality in renal 
insufficiency namely the retention of urine in blood. ${ }^{1}$

Merrill et al (1953) ${ }^{2}$ observed excellent clinical response even when blood urea remained high pre and post dialysis confirming the impression that urea played little role in the clinical toxicity of uremia and that elevated blood urea level on the other hand served a useful function in maintain urine volume.

Metabolic encephalopathy (renal, hepatic and pulmonary dysfunction) stressed acidosis as underlying fault in neurologic dysfunction by Posner \& plum (1967) ${ }^{3}$.

Considering the sparsity of such studies which are a few in India and an attempt will be made to correlate them with clinical and biochemical profile of the uremic patients.

\section{Material \& Methods}

A prospective study done on 25 cases of uremia due to varied etiology were selected from the wards of general hospital, Dungarpur, Rajasthan. The cases were diagnosed on the basis of the criteria laid down by Jean Hamburger, Richet G. et al $(1968)^{4}$. Cases were considered to be having renal failure if their blood urea level was over 50 $\mathrm{mg} \%$ of these, those having urine output below $400 \mathrm{ml}$ per 24 hour were grouped as cases of acute renal failure and those having urine output $400 \mathrm{ml}$ were grouped as having chronic renal failure.
A detailed history of each patient was taken with special references to weight loss, weight gain, fever, dyspnoea, vomiting, diarrhea, puffiness face, swelling feet, anasarca, thirst, hicupp, pruritis, retention urine, frequency urine, oliguria, polyurea, acuity of vision, muscular twitching and tremors so as to exclude other major diseases and to delineate the extent of renal failure.

A routine examination of hemoglobin, ESR, TLC, DLC, Complete urine examination with references to 24 hours urine volume, specific gravity and $\mathrm{pH}$ was done. Biochemical estimation of blood urea, serum Creatinine, sodium and potassium was also done.

\section{Results}

Our study showed that maximum no. of cases $(52 \%)$ affected were from the range of 31-50 years, males were more preponderance as compared to females (table 1). In biochemical analysis, the blood urea and serum Creatinine was higher and serum sodium \& potassium within normal range (table 2).

Out of 25 cases, 16 were alert and 9 cases were drowsy. Drowsy patients had elevated urea, Creatinine, and potassium levels and less sodium level as compared to alert patients. The changes of mean value in different groups was seen in table no. 5 .

Table 1: Age \& sex incidence of cases

\begin{tabular}{|l|c|c|c|}
\hline Age group (years) & Male & Female & Total \\
\hline$\leq 10$ yrs & 2 & 0 & 2 \\
\hline $11-20$ yrs & 2 & 1 & 3 \\
\hline $21-30$ yrs & 3 & 1 & 4 \\
\hline $31-40$ yrs & 5 & 2 & 7 \\
\hline $41-50$ yrs & 5 & 1 & 6 \\
\hline$>50$ yrs & 2 & 1 & 3 \\
\hline Total & 19 & 6 & 25 \\
\hline
\end{tabular}

Table 2: Biochemical values in 25 cases of uremia

\begin{tabular}{|l|c|c|c|}
\hline Blood parameters & Mean value & Range & Normal (Harrison's) \\
\hline Blood urea & $150.4 \mathrm{mg} / \mathrm{dl}$ & $74-245 \mathrm{mg} / \mathrm{dl}$ & $15-40 \mathrm{mg} / \mathrm{dl}$ \\
\hline Serum Creatinine & $6.2 \mathrm{mg} / \mathrm{dl}$ & $1.2-13.4 \mathrm{mg} / \mathrm{dl}$ & $<1.5 \mathrm{mg} / \mathrm{dl}$ \\
\hline Serum Sodium & $138.9 \mathrm{meq} / \mathrm{l}$ & $124-150 \mathrm{meq} / \mathrm{l}$ & $136-145 \mathrm{meq} / \mathrm{l}$ \\
\hline Serum Potassium & $5.0 \mathrm{meq} / \mathrm{l}$ & $3.5-5.8 \mathrm{meq} / \mathrm{l}$ & $3.5-5.0 \mathrm{meq} / \mathrm{l}$ \\
\hline
\end{tabular}


Table 3: Dividation of different groups

\begin{tabular}{|l|c|c|c|c|}
\hline Groups & Group I & Group II & Group III & Group IV \\
\hline Level of consciousness & Alert & Drowsy & - & - \\
\hline Blood urea & $50-100 \mathrm{mg} / \mathrm{dl}$ & $101-150 \mathrm{mg} / \mathrm{dl}$ & $151-200 \mathrm{mg} / \mathrm{dl}$ & $>201 \mathrm{mg} / \mathrm{dl}$ \\
\hline Serum Creatinine & $<1.5 \mathrm{mg} / \mathrm{dl}$ & $1.5-10 \mathrm{mg} / \mathrm{dl}$ & $>10 \mathrm{mg} / \mathrm{dl}$ & - \\
\hline Serum Sodium & $<136 \mathrm{meq} / \mathrm{l}$ & $136-145 \mathrm{meq} / \mathrm{l}$ & $>145 \mathrm{meq} / \mathrm{l}$ & \\
\hline Serum Potassium & $3.4-5.0 \mathrm{meq} / \mathrm{l}$ & $>5.0 \mathrm{meq} / \mathrm{l}$ & - & - \\
\hline
\end{tabular}

Table 4: Mean biochemical profile (Alert v/s Drowsy)

\begin{tabular}{|l|c|c|c|c|c|}
\hline $\begin{array}{l}\text { Level of } \\
\text { consciousness }\end{array}$ & $\begin{array}{c}\text { No. of } \\
\text { cases }\end{array}$ & $\begin{array}{c}\text { Blood urea } \\
\mathrm{mg} / \mathrm{dl}\end{array}$ & $\begin{array}{c}\text { Serum Creatinine } \\
\mathrm{mg} / \mathrm{dl}\end{array}$ & $\begin{array}{c}\text { Serum Sodium } \\
\mathrm{meq} / \mathrm{lit} .\end{array}$ & $\begin{array}{c}\text { Serum Potassium } \\
\mathrm{meq} / \mathrm{lit} .\end{array}$ \\
\hline Alert & 16 & 124.9 & 4.5 & 137.1 & 4.6 \\
\hline Drowsy & 9 & 166.6 & 7.1 & 126.9 & 5.3 \\
\hline
\end{tabular}

Table 5: Mean biochemical profile

\begin{tabular}{|l|c|c|c|c|c|c|c|c|}
\hline \multirow{2}{*}{ Group } & \multicolumn{2}{|c|}{ Group I } & \multicolumn{2}{c|}{ Group II } & \multicolumn{2}{c|}{ Group III } & \multicolumn{2}{c|}{ Group IV } \\
\cline { 2 - 10 } & No. & Mean & No. & Mean & No. & Mean & No. & Mean \\
\hline Blood urea mg/dl & 7 & 85.1 & 8 & 122.6 & 6 & 172.8 & 4 & 221.2 \\
\hline Serum Creatinine mg/dl & 1 & 1.2 & 21 & 4.8 & 3 & 12.9 & - & - \\
\hline Serum Sodium meq/lit. & 16 & 128.5 & 6 & 138.5 & 3 & 149.6 & - & - \\
\hline Serum Potassium meq/lit. & 17 & 4.5 & 8 & 5.5 & - & - & - & - \\
\hline
\end{tabular}

\section{Discussion}

The mean biochemical profile irrespective of clinical picture and level of consciousness was blood urea $150.4 \mathrm{mg} / \mathrm{dl}$, serum Creatinine 6.2 $\mathrm{mg} / \mathrm{dl}$, serum sodium $138.9 \mathrm{meq} / \mathrm{lit}$. and serum potassium $5.0 \mathrm{meq} / \mathrm{lit}$. in 25 cases in our study.

The clinical and biochemical correlation in uremic patients as discussed above has been attempted by several workers in well equipped laboratories. Some did achieve a significant correlation but then it was influenced by several factors as level of consciousness, age, electrolyte disturbance, $\mathrm{pH}$, $\mathrm{CO}_{2}$ content of blood, urea, Creatinine, $\mathrm{Hb}$ level, that unless each factor is singled out it is impossible to attribute one specific biochemical parameter for slowing of EEG.

Widal et al in 1903 for the first time commented that there were many facets of renal failure and all the confusion stemmed from the attempt to link all the complications to one single mechanism.

Schreiner $(1957)^{5}$ suggested deranged protein metabolism for uremic toxicity. Tyler et al (1968) ${ }^{6}$ found defect in sodium potassium pump or membrane defect in uremic patients.

Quastel (1958) ${ }^{7}$ observed that metabolic encephalopathy could be the results of insufficiency of substrate, oxygen or interference with cerebral enzyme activity and transport of metabolites such as aminoacids \& electrolytes in to nerve cells. All or combination of theses mechanism were responsible for cerebral dysfunction due to liver, kidney or lung disease.

Balslor et al $(1965)^{8}$ observed that mortality was $34 \%$ in patients with blood urea less than $300 \mathrm{mg} \%$ and $78 \%$ in cases with blood urea above $500 \mathrm{mg} \%$.

Inspite of extensive work on uremia until today the exact etiopathological agent responsible for the clinical toxicity of uremia could not be single out. The encephalopathies appeared to be more related to the rate of change of ion concentration than to the nature of the change of the involved ion.

\section{Conclusion}

We concluded that the blood urea and serum Creatinine was higher and serum sodium \& potassium within normal range. Hyponatremia and patients with blood urea above $201 \mathrm{mg} \%$ had relatively less significant positive correlation. Uremic patients irrespective of biochemical and clinical parameters which has not been mentioned by earlier workers. 


\section{References}

1. Brenner B.M. \& Rector F.C; Chronic renal failure. The Kidney, Saunders; 1976; Section 4:1423-1480.

2. Merrill J.P.; Observation on the role of urea in uremia. American J. Medicine, 1953;14:519-520.

3. Posner JB \& Plum F. Spinal fluid $\mathrm{pH} \&$ neurological symptoms in acidosis. New England Journal of Medicine, 1967;277:605-613.

4. Hamburger Jean et al; Nephrology, Saunders, 1968; vol. 1:275-362.

5. Schreiner, GR. Mental \& personality changes in uremic syndrome. Medical annals D.C. 1957;28:316-329.

6. Tyler H.R. Neurological disorders in renal failure. American Journal Medicine, 1968;44:734-738.

7. Quastel J.H. \& Scholifield; Biochemical aspects of cerebral dysfunction. American J. Medicine, 1958.

8. Balslor JJ \& Jorgensen HE; A survey of 499 patients with acute anuric renal insufficiency. American J. Med. 1965;34:753. 